\title{
Information Asymmetry Surrounding Earnings and Dividend Announcements: An Intra-day Analysis
}

\author{
Janice CY How, Caro X Huang, Peter Verhoeven \\ Department of Finance and Banking, Curtin University of Technology
}

\begin{abstract}
This paper uses high frequency data to evaluate whether information asymmetry in the market is reduced as a result of corporate earnings and dividend announcements. Changes in the level of information asymmetry due to the announcements are proxied by the rate of change in trading volume, bid-ask spread, cumulative abnormal returns, and order imbalance. Our results show support for an information asymmetry reduction due to the release of corporate earnings and dividend for all proxies of information asymmetry except for trading volume. Cross-sectional analysis shows that firm size and forecast errors are the two main explanatory variables for the change in information asymmetry.
\end{abstract}

Keywords: Earnings and dividend announcements; information asymmetry; high frequency data

\section{INTRODUCTION}

Early empirical studies on the information content of corporate announcements examine price movements (Ball and Brown, 1968) and volume changes (Beaver, 1968). Volume reactions and changes in the equilibrium prices reflect individual investor's altered expectations. These studies support the notion that corporate public announcements are informative.

Insofar as the announcement contains value-relevant information, it is often argued that the level of information asymmetry in the market is reduced subsequent to the announcement (Lee, et al., 1993). To our knowledge, only Brooks (1996) has investigated the change in asymmetric information at earnings and dividend announcements. Based on Hasbrouck's (1991) model, his results show a fall in the level of information asymmetry around earnings but not dividend announcements. ${ }^{1}$ He suggests that dividend announcements may be important for reasons other than a reduction in information asymmetry, e.g., in conveying knowledge about the ex-dividend date.

This study revaluates the degree to which information asymmetry in the market is reduced as a result of corporate announcements of earnings and dividend using high frequency data. It also tests whether the extent of the reduction is dependent on the nature of the

\footnotetext{
${ }^{1}$ This result is consistent with Beaver (1968), Morse (1981), and Patell and Wolfson (1984).
}

announcements, i.e., "good" or "bad" news. We choose earnings and dividend announcements not only because they are undoubtedly the most researched corporate announcements in the academic literature, but more importantly because they can be objectively and easily grouped as either positive or negative news using well-established expectation models.

We proxy information asymmetry by the rate of change in trading volume, bid-ask spread, cumulative abnormal returns, and order imbalance in this study. Our results find a reduction in information asymmetry following earnings and dividend announcements when information asymmetry is proxied by order imbalance, bid-ask spread, and cumulative abnormal returns. However, there is no significant increase in trading volume following these announcements. Cross-sectional analysis suggests that the extent of information asymmetry reduction is smaller for larger firms than for smaller firms. The change in information asymmetry is greater for firms with higher earnings and dividend forecast error. Since earnings and dividend are announced simultaneously about 97 percent of the time in Australia (Brown et al., 1977; How et al., 1992), we control for their interactive effect. The results show that the interaction between earnings and dividend forecast errors is significant in explaining the degree of the reduction in information asymmetry. 
The rest of this paper is structured as follows. The next section sets out our hypotheses, Section 3 discusses our data, Section 4 provides the results, and Section 5 concludes.

\section{HYPOTHESES}

Consistent with previous studies, we expect the announcements of earnings and dividends to have information content and will therefore result in a reduction of information asymmetry in the market. Our first hypothesis is:

H1: The level of information asymmetry in the market is reduced after earnings and dividends announcements.

Bamber (1987) states that small firms are less monitored compared to large firms. This suggests that, all else equal, small firms' announcements are more informative vis-à-vis large firms' announcements. The stock price of large firms also tends to adjust to market information faster than the stock price of small firms (Yu and Wu, 2001). Bhushan (1989) proposes that this can be due to the less costly information acquisition for large firms than for small firms. Therefore, the amount of information available (and thus the extent of information asymmetry) is an increasing function of firm size (How and Yeo, 2001) so that the market reaction to small firms' announcements is expected to be greater than that to large firms' announcements. This has support in Waymire (1985). We thus hypothesise:

\section{H2: The reduction in information asymmetry due to earnings and dividend announcements is negatively related to firm size.}

Past evidence shows that earnings and dividend announcements have information content (Kane et al., 1984; Leftwich and Zmijewski, 1994) and that the extent of the market reaction depends on earnings and dividend forecast errors (McNichols, 19891; Lev and Penman, 1990). Lees (1981) also theorises that inaccurate forecasts convey the impression that the firm is unstable, leading to the perception of high risk and therefore lower share price. How and Yeo (2001) find that firms with larger forecast errors have more negative price reaction on the announcement date than firms with smaller forecast error. In line with the above findings, we expect firms with higher forecast error to have a higher level of portfolio revision after earnings and dividend announcements. This leads us to the next hypothesis:
H3: The reduction in information asymmetry due to earnings and dividend announcements is positively related to the forecast error.

\section{DATA AND RESEARCH METHODS}

This study draws upon a sample of the top 200 firms listed on the Australian Stock Exchange (ASX) from 1998 to 1999 . We require the sample firms to have made earnings and/or dividend announcements in both years. They must also have complete intraday information and do not have a trading halt right after the announcement(s). These selection criteria result in a final sample of 109 firms.

High frequency data for sample firms are obtained from the Securities Industry Research Centre of Asia Pacific (SIRCA). These data include the volume of bids and asks in the limit order book for the five best quotes, the bid-ask spread, the midpoint of the bid-ask spread, the cumulative volume traded, the price traded and the corresponding Share Price Index (SPI). The date and time of the ASX 200 firms' earnings and dividend announcements are obtained from the ASX's Signal-G. Datastream provides historical daily closing prices of the firms, SPI, and the number of outstanding shares. Analysts' forecasts of earnings and dividend and industry codes for the ASX200 firms are extracted from the $\mathrm{I} / \mathrm{B} / \mathrm{E} / \mathrm{S}$ database.

We refer to the literature to inform us on how to best capture the change in the level of information asymmetry surrounding public announcements. Kim and Verrecchia (1991a) find that each investor achieves his optimal portfolio prior to a public disclosure by trading on predisclosure information and other information that he is privy to in the predisclosure period. The average change in investors' beliefs after the information is publicly announced induces changes in both price and trading volume. Because private information is acquired in different degrees of precision, investors are asymmetrically informed, and this leads them to form different predisclosure expectations. This results in differential belief revisions when annual earnings and dividend are announced and in turn, induces share price and trading volume reactions. Changes in share price and trading volume can therefore be viewed as a consequence of a change in the level of information asymmetry. Here, we expect an increase in both the cumulative share 
returns and trading volume after earnings and dividend announcements. Trading volume is the dollar value ${ }^{2}$ of cumulative volume at the specific time-interval from 120 to +120 minutes surrounding the earnings and dividend announcements:

$$
V O L_{i, t}=\frac{\sum\left(V_{i, t} * P_{i, t}\right)}{C P_{i, t} * O_{\text {UTSH }}}
$$

where for firm i at time interval t, $V O L$ is cumulative dollar volume; $V$ is cumulative number of shares; $P$ is the last traded price; $C P$ is the closing price; and OUTSH is the number of outstanding shares. To measure the cumulative abnormal returns for the event study window, abnormal returns are first derived using the market model. We then cumulate the abnormal returns across the event window:

$$
C A A R_{t}=\sum A A R_{t}
$$

where $C A A R_{i, t}$ is cumulative average abnormal return of all firms at time $t$; and $A A R_{i, t}$ is the average abnormal return for firm $i$ at time $t$.

Changes in bid-ask spreads can also indicate changes in information asymmetry. Intuitively, we expect the spread to narrow after an announcement (Acker et al., 2000). This is due partly to market-makers quoting narrower spreads once the announcement is made since informed investors no longer have "advance knowledge of earnings". Also, significant increases in trading volume around the announcements should lead to lower spreads. This is because in a liquid ${ }^{3}$ market characterized by high trading volumes, the market maker is assured of being able to quickly restore an out-of-equilibrium position. Therefore, as liquidity of a stock increases, the compensation required by the market-maker through the spread is reduced, resulting in a negative relationship between trading volumes and spreads. The bid-ask spread is computed by taking the difference between the best bid and the best ask prices at the stipulated times and divide it by the mid-point of the spread.

\footnotetext{
${ }^{2}$ Dollar value volume is used to control for differences in share price, and it is divided by market capitalization (total number of outstanding shares and closing price) on the day of the announcement.

3 Kyle (1985) notes that the term market liquidity encompasses a number of transactional properties, and trading volume can be used as a measure of liquidity.
}

$$
S P R_{i, t}=\left(\frac{A S K_{i, t}-B I D_{i, t}}{M I D P T_{i, t}}\right)
$$

where for firm $\mathrm{i}$ at time interval $\mathrm{t}, S P R$ is the percentage bid-ask spread; $A S K$ is the best ask price; $B I D$ is the best bid price; and MIDPT is the midpoint of bid-ask spread.

Changes in information asymmetry can also be captured by market-wide order imbalance. Chordia et al. (2001) find the order imbalance pattern to be a consistent inventory paradigm. ${ }^{4}$ Their study shows that investors are contrarians in aggregate, i.e., they are net sellers after market rises and vice versa. This indicates that if investors are successful in this endeavor, temporary price pressures are in general effectively countervailed by financial market investors. There is also strong evidence showing that changes in liquidity can be predicted using market returns. In particular, liquidity falls following market declines. As noted previously, trading volume can be a measure of market liquidity. Thus trading volume and order-imbalance are positively related, implying that the orderimbalance in the market increases after earnings and dividends announcements. Order imbalance is measured by taking the larger value of total volume of top 5 ask or bid quotes and dividing it by the smaller of the two:

$$
O I_{i, t}=\frac{b V 5_{i, t}}{s V 5_{i, t}}
$$

where for firm $\mathrm{i}$ at time interval $\mathrm{t}, O I$ is order imbalance before and after the announcement; $b \mathrm{~V} 5$ is the bigger of total volume of top 5 ask or bid quotes; and $s V 5$ is the smaller of total volume of top 5 ask or bid quotes.

To measure the change in information asymmetry due to the release of earnings and dividend outcomes, we look at the difference in the information asymmetry metric before and after the announcement. We calibrate the change in three ways:

\footnotetext{
${ }^{4}$ In particular, the paradigm suggests that after an event that causes a large inventory imbalance on one side of the market, market-makers set quotes to elicit trading on the other side of the market.
} 
1) Ratio $1=\frac{P O S T_{i, t}-P R E_{i, t}}{P R E_{i, t}}$

2) Ratio $2=P O S T_{i, t}-P R E_{i, t}$

3) Ratio3 $=\frac{P O S T_{i, t}}{P R E_{i, t}}$

where for firm i at time t, PRE and POST denote the variable of interest before and after the announcement respectively.

We use the naive model to estimate the forecast errors in earnings and dividend. The model assumes annual earnings to follow random walk. We also measure the forecast errors in earnings and dividend using analysts' forecasts.

To examine cross-sectional differences in the change in information asymmetry due to earnings and dividend announcements, we run the following regression. To recap, the change in information asymmetry is proxied by changes in traded volume, bid-ask spread, order imbalance, and cumulative share price returns:

$\Delta \mathrm{IA}=\delta_{\mathrm{i}, \mathrm{t}}+\alpha_{2}\left|\mathrm{UE}_{\mathrm{i}, \mathrm{t}}\right| . \mathrm{I}+\alpha_{4}\left|\mathrm{UD}_{\mathrm{i}, \mathrm{t}}\right| . \mathrm{J}+\alpha_{5} \mathrm{SIZE}_{\mathrm{i}, \mathrm{t}}+$ $\alpha_{6} \mathrm{IND}_{\mathrm{i}}+\alpha_{7} \mathrm{UE}_{\mathrm{i}, \mathrm{t}}+\alpha_{8} \mathrm{UE}_{\mathrm{i}, \mathrm{t}-1}+\alpha_{9} \mathrm{UD}_{\mathrm{i}, \mathrm{t}}+\alpha_{10} \mathrm{UD}_{\mathrm{i}, \mathrm{t}-1}+$ $\alpha_{11}(++)_{\mathrm{i}, \mathrm{t}}+\alpha_{12}(+-)_{\mathrm{i}, \mathrm{t}}+\alpha_{13}(-+)_{\mathrm{i}, \mathrm{t}}+\alpha_{14}(+0)_{\mathrm{i}, \mathrm{t}}+\alpha_{15}(-$ $0)_{\mathrm{i}, \mathrm{t}}+\alpha_{16}$ TIME $_{\mathrm{i}}+\alpha_{17}$ TIME $_{\mathrm{i}}+\alpha_{18}$ TIME $_{3}+\alpha_{19}$ TIME $_{\mathrm{i}}+\alpha_{20}$ TIME $_{\mathrm{i}}+\alpha_{21}$ PUE $_{\mathrm{i}, \mathrm{t}}+\alpha_{22}$ PUD $_{\mathrm{i}, \mathrm{t}}+\varepsilon_{\mathrm{i}, \mathrm{t}}$ ... (10)

Here, TIME is an indicator of the timing of the announcement. In order to isolate the marginal informational content of earnings and dividend announcements, interactive dummies based on the directional change in earnings and dividend forecast errors, as in Kane et al. (1984), are included in the regression. A dummy variable is assigned to each of the following combinations of earnings and dividend forecast errors: $(++),(+-),(-+),(+0),(-0)$ and $(--)$. The sign in the parentheses denote the directional change in earnings and dividend relative to the forecast figures. For example, $(++)$ denotes firms with positive earnings and dividend forecast errors. The interactive term (--) is the base case in the test._We also control for industry effects in the test.

\section{RESULTS \\ (Tables of results to be provided upon request)}

We first conduct univariate tests of differences in the level of trading volume, bid-ask spread, order imbalance, and cumulative abnormal returns before and after earnings and dividend announcements using t-tests and non-parametric Mann-Whitney tests.

The results show that with the exception of trading volume, all the proxies exhibit significant differences before the announcements. Specifically, on average, the level of information asymmetry in the market is reduced after earnings and dividend announcements. Tests on the cumulative abnormal returns show that there is information content in earnings and dividend announcements.

We then run cross-sectional multiple OLS regressions on the relationship between the change in information asymmetry and various explanatory variables as hypothesized earlier (results to be provided). For robustness, we use the three ratios of each information asymmetry metric and the two earnings and dividend expectation models (i.e., analyst forecasts and naïve).

Regardless of how we calibrate the change in order imbalance, our results show that the lower the analysts' dividend forecast error, the larger the decrease in order imbalance. This result is expected and consistent with Kim and Verrecchia (1991a, 1991b). They find that heterogeneous beliefs induce market participants to trade. The higher the information asymmetry at the announcement date, the greater are the trading volume and spreads. The results on earnings forecast errors are less significant and tend to be rather sensitive to the way we proxy the change in order imbalance.

There is evidence showing that the interaction between earnings and dividend forecast errors is related to the change in information asymmetry, as proxied by the change in order imbalance. Specifically, we find that the coefficient of (+-) is significantly negative for Ratio1 and Ratio3, suggesting that firms with a positive earnings forecast error and a negative dividend forecast error (estimated using analyst forecasts), on average, have a lower change in order imbalance. Firms with a negative earnings forecast error and positive dividend forecast error, on the other hand, 
experience a greater change in order imbalance due to the release of earnings and dividend outcomes.

The timing of the announcement appears to be an important factor, with firms that made an announcement in the first and fifth hours of trading have a smaller change in order imbalance compared to the companies that make their announcements in the last hour of trading. Firm size (SIZE) also has explanatory power, with larger firms having a lower increase in order imbalance than smaller firms. A plausible explanation for this is that larger firms have a larger analyst following and more information available publicly. Therefore, announcements of larger firms have lower information content than smaller firms since most of the information has already been anticipated by the market. We also note that the relationship between (earnings and dividend) forecast errors and the change in order imbalance does not appear to be sensitive to the way we measure forecast error. It is worth noting that PUE_t has a significantly negative coefficient in this set of regressions. This means the sign of the previous unexpected earnings and the sign of the current unexpected earnings have explanatory power.

When we use bid-ask spread as the dependent variable, firm size is significant. This implies that the bigger the size of the firm, the higher the reduction of bid-ask spread, contrary to our predictions. (+-) is significantly positive for all the regressions, suggesting that firms with a positive earnings forecast error and a negative dividend forecast error on average have a higher change in bid-ask spread after announcements. As before, the timing of the announcement affects the extent of the reduction in information asymmetry.

When the dependent variable is bid-ask spread, similar results are found for SIZE. The results also show that the higher the unexpected dividends, the larger the decrease in bid-ask spread. Interactive terms $(-+),(+0)$ and $(-0)$ are significantly negative for most regression.

Using trading volume as a proxy for information asymmetry yields results that support the notion that the higher the level of unexpected earnings, the larger the decrease in trading volume after announcements. In line with our predictions, the higher the level of unexpected dividends in the current and previous period, the larger the increase in trading volume. Also consistent with our hypothesis, we find that the larger the firm, the smaller the change in trading volume after announcement. The increase in trading volume for firms with a positive earnings forecast error and a negative dividend forecast error is lower that that of firms with negative earnings and dividend forecast errors (base). Some supporting evidence is again found for the importance of the timing of the announcements. Specifically, there is a smaller increase in trading volume for firms that makes announcements in the third hour of trading compared to firms that make announcements in the last hour of trading.

\section{SUMMARY AND CONCLUSION}

This study is based on the premise that earnings and dividend announcements have information content, and therefore the release of such information will induce market reactions. The rate of change in order imbalance, trading volume, bid-ask spread, and cumulative abnormal returns are used as proxies for the change in information asymmetry. We find that there is significant reduction in order imbalance, and bid-ask spread after earnings and dividend announcements. There is a difference in the trading volume before and after earnings and dividend announcement but the difference is not significant. Overall, the results are consistent with our prediction that information asymmetry reduces after earnings and dividend announcements, implying that these events contain new information. We also find that firm size and forecast errors are the two main explanatory variables for the change in information asymmetry in our sample.

\section{REFERENCES}

Acker, D., Stalker, M., Tonks, I., 2000, Bid-Ask Spreads Around Earnings Announcements, working paper, University of Bristol.

Atiase, R., K., 1985, Predisclosure Information, Firm Capitalisation and Security Price Behaviour Around Earnings Announcements, Journal of Accounting Research 23, 21-35.

Ball, R., Brown, P., 1968, An Empirical Evaluation of Accounting Income Numbers, Journal of Accounting Research, 159-178.

Bamber, L.,S., 1986, The Information Content of Annual Earnings Releases: A Trading Volume Approach, Journal of Accounting Research 24, 40-56.

Beaver, W., H., 1968, The Information Content of Annual Earnings Announcements, Empirical Research in Accounting: Selected Studies, Journal of Accounting Research 6, 67-92. 
Bhushan, R., 1989, Collection of Information about Publicly Traded Firms: Theory and Evidence, Journal of Accounting and Economics 11, 183-206.

Brooks, R., M., 1996, Changes in Asymmetric Information at Earnings and Dividend Announcements, Journal of Business Finance and Accounting 23, 359-378.

Brown, P., D., Finn, F., Hancock, P., 1977, Dividend Changes, Earnings Reports and Share Prices: Some Australian Findings, Australian Journal of Management, 2, 127-147.

Hasbrouck, J., 1991, Measuring the Information Content of Stock Trades, Journal of Finance 46, 179-207.

How, J., Teo, C., Izan, H., 1992, The Interaction Effect of Earnings and Dividends on Share Prices:
Australian evidence, Managerial Finance 18, 40-60.

How, J., Yeo, J., 2001, The Impact of Forecast Disclosure and Accuracy on Equity Pricing: The IPO Perspective, Journal ofAccounting, Auditing and Finance 16, 401-425.

Kane, A., Lee, Y., Marcus, A., 1984, Earnings and Dividend Announcements: Is there Corroboration Effect?. The Journal of Finance 39, 1091-1099.

Lee, C., 1992, Earnings News and Small Traders: An Intraday Analysis, Journal of Accounting and Economics 15, 265-302.

Verrecchia, R., E., 1980, The Rapidity of Price Adjustments to Information, Journal of Accounting and Economics 2, 63-92. 